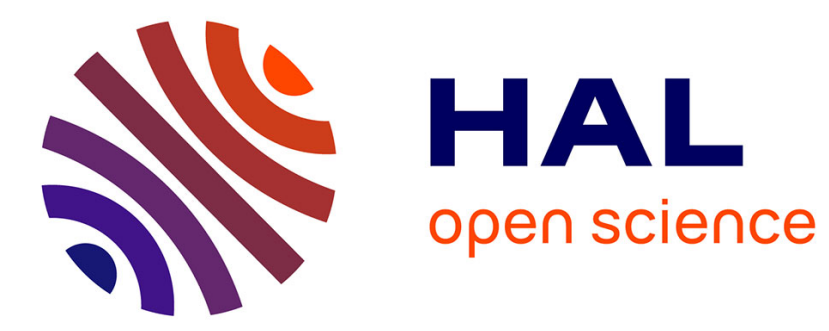

\title{
Reply to a brief comment on the past and present of surgical treatment of cardiac wounds
}

\author{
Erwan Flécher, Alain Leguerrier, Nicolas Nesseler
}

\section{To cite this version:}

Erwan Flécher, Alain Leguerrier, Nicolas Nesseler. Reply to a brief comment on the past and present of surgical treatment of cardiac wounds. Journal of Cardiac Surgery, 2020, 35 (11), pp.3254-3254. 10.1111/jocs.15046 . hal-03039972

\section{HAL Id: hal-03039972 \\ https://hal.science/hal-03039972}

Submitted on 15 Dec 2020

HAL is a multi-disciplinary open access archive for the deposit and dissemination of scientific research documents, whether they are published or not. The documents may come from teaching and research institutions in France or abroad, or from public or private research centers.
L'archive ouverte pluridisciplinaire HAL, est destinée au dépôt et à la diffusion de documents scientifiques de niveau recherche, publiés ou non, émanant des établissements d'enseignement et de recherche français ou étrangers, des laboratoires publics ou privés. 


\section{Reply to a brief comment on the past and present of surgical treatment of cardiac wounds}

Erwan Flécher ${ }^{1} \quad$ http://orcid.org/0000-0003-1379-0438

Alain Leguerrier ${ }^{1}$

Nicolas Nesseler ${ }^{2}$

Correspondence

Erwan Flécher, Service de Chirurgie Thoracique et Cardio-vasculaire, CHU de Rennes, 2 rue Henri Le Guilloux, 35000 Rennes, France. Email: erwan.flecher@chu-rennes.fr

${ }^{1}$ Department of cardiothoracic and vascular surgery, University Rennes

Hospital, INSERM, Rennes, France

${ }^{2}$ Department of Anesthesia, University Rennes Hospital, Rennes, France

Dear Editor,

First we would like to thank Dr Lopez de la Cruz for her comments and interest about our recently published article "the odyssey of suturing cardiac wounds: lessons from the past."

We highly appreciated and agree with the complements she made especially about Larrey and Milton role in this field. One should also note Theodore Tuffier's attempt at cardiac resuscitation in 1898 in a young man dying on the wards at La Pitie Hospital (Paris). ${ }^{1}$ Although this act was performed on an unwounded heart it adds information about the history of surgical approach in such dramatic condition.

We do recognize left anterolateral thoracotomy as the gold standard in an emergency room to treat a penetrating cardiac injury. However a median longitudinal sternotomy may be discussed in our opinion if the patient arrived directly in a cardiac surgery operating theater. The patent presented in our paper was directly brought in our operative theater of cardiac surgery and managed immediately by cardiac surgeons and cardiac an-esthesiologists, with a cardiopulmonary bypass ready, dedicated scrub nurses and perfusionist. In such specific conditions a sternotomy may be discussed, depending on the context and the anatomical suspected lesions (it was the option retained in the presented case and the surgical procedure was safely performed with good outcome). Clearly, in a peripheral hospital or at the emergency room sternotomy is not an option to be considered and we agree with Dr Lopez de la Cruz .

\section{REFERENCE}

1. Anthony R, Dobell C. Theodore Tuffier's attempt at cardiac resuscitation. Ann Thorac Surg. 1993;56:583-584. 